\begin{tabular}{|lcc|}
\hline & TOTOBUANG & \\
\hline Volume 6 & Nomor 1, Juni 2018 & Halaman 69-80 \\
\hline
\end{tabular}

\title{
KAJIAN LATAR FISIK DAN LATAR SOSIAL YANG TERCERMIN DALAM NOVEL PERTEMUAN DUA HATI KARYA NH. DINI (A review of the physical background and social setting that is reflected in the novel of "Pertemuan Dua Hati" by NH. DINI)
}

\author{
Sakila \\ SMP Negeri 2 Singkawang \\ Jalan Pahlawan, Kota Singkawang, Indonesia \\ Pos-el: sakilaspd@yahoo.co.id
}

(Diterima: 6 Februari 2018; Direvisi 24 Mei 2018; Disetujui: 30 Mei 2018)

\begin{abstract}
The purpose of this study commonly described about the background of the Pertemuan Dua Hati novel and specifically interpreted its physical background and social setting. The research used descriptive method with qualitative research model. The research approach was using structural approach. The source of the data was taken from a novel entitled Pertemuan Dua Hati by Nh. Dini which had been published by PT Gramedia Pustaka Utama, Jakarta, in 1992, the sixth printing, and consists of 85 pages. Based on the analysis, it concluded that the physical setting that presented by the author was quite well. This can be seen from the description of the house and the area. Furthermore, the social background that presented by the author was good enough. It has been explanated from the conditional economy, the views of life and the attitude of the character.
\end{abstract}

Keywords: Novel, Pertemuan Dua Hati, physical setting, social setting.

Abstrak

Tujuan penelitian ini secara umum adalah untuk mendeskripsikan latar dalam novel Pertemuan Dua Hati, sedangkan secara khusus untuk menginterpretasikan latar fisik dan latar sosial novel tersebut. Metode penelitian yang digunakan adalah metode deskriptif dengan model penelitian kualitatif. Pendekatan penelitian yang digunakan adalah pendekatan struktural. Sumber datanya berasal dari novel yang berjudul Pertemuan Dua Hati karya Nh. Dini yang diterbitkan oleh PT Gramedia Pustaka Utama, Jakarta, tahun 1992, cetakan keenam, dan terdiri dari 85 halaman. Berdasarkan hasil analisis terhadap novel tersebut, latar fisik yang disajikan pengarang cukup baik. Hal ini terlihat dari keterangan mengenai rumah dan daerah. Selanjutnya, latar sosial yang disajikan pengarang cukup baik. Hal ini terlihat dari pemaparan tentang keadaan ekonomi, pandangan hidup, dan sikap hidup tokoh.

Kata-kata kunci: Novel, Pertemuan Dua Hati, latar fisik, latar sosial.

\section{PENDAHULUAN}

Sastra adalah ungkapan pribadi manusia yang berupa pengalaman, pemikiran, perasaan, ide, semangat keyakinan dalam suatu bentuk gambaran kongkrit yang membangkitkan pesona dengan bahasa sebagai alat (Sumardjo dan Saini, 1986:3).

Sastra sebagai ungkapan pribadi manusia yang bersifat imajinatif, dalam kehidupan sehari-hari dapat berfungsi untuk memperjelas, memperdalam, dan memperkaya pengalaman serta penghayatan yang lebih baik itu manusia dapat bersikap untuk menciptakan kehidupan yang sejahtera (Sumardjo dan Saini, 1986:16).

Salah satu bentuk karya sastra yang dapat mewakili seperti dikemukakan di atas adalah novel. Novel dapat berisi tentang sesuatu yang mungkin terjadi atau tidak sama sekali. Selain itu, novel juga merupakan salah satu sarana yang efektif atau media yang tepat untuk memahami kehidupan. Oleh karena itu, novel dengan cepat leluasa merefleksikan kenyataan dari berbagai kehidupan di masyarakat.

Bagian dari unsur yang membangun karya sastra, seperti novel adalah unsur latar. 
Latar merupakan salah satu bagian yang berperan penting dalam cerita rekaan. Latar yang digarap dengan baik sangat berpengaruh terhadap imajinasi pembaca. Selain itu, latar merupakan unsur karya sastra yang menjadi latar belakang segala peristiwa yang terjadi dalam karya sastra (Effendy, 1985:41). Latar juga berkaitan dengan nilai-nilai kehidupan manusia seperti adat-istiadat, norma, dan tingkah laku yang kesemuanya menjadi bagian kehidupan manusia.

Latar atau seting memiliki fungsi yang penting bagi sebuah novel. Kelemahan pada latar akan menimbulkan ketimpangan tensi dan emosi tokoh. Dikatakan demikian karena latar atau seting turut memberikan nuansa cerita.

Latar dalam novel antara lain terdiri dari latar fisik dan latar sosial. Latar fisik meliputi tempat dan daerah, sedangkan latar sosial meliputi keadaan ekonomi, pandangan hidup dan sikap hidup.

Novel yang tidak memiliki latar fisik membuat pembaca bertanya-tanya di mana tempat dan daerah terjadinya cerita tersebut. Begitu pula apabila novel tidak memiliki latar sosial akan menyebabkan pembaca menjadi bingung tentang sikap hidup sang tokoh atau pembaca berkesimpulan mungkin pengarang belum mampu menentukan pandangan hidup seorang tokoh dalam novel. Selanjutnya, dapat dikatakan bahwa pengarang yang berpengalaman adalah pengarang yang mampu melukiskan latar fisik dan latar sosial secara kongkret.

Mengingat pentingnya fungsi latar dalam novel, sehingga penelitian ini difokuskan pada latar, terutama latar fisik dan latar sosial. Hasil penelitian diharapkan dapat memberikan gambaran kongkrit tentang latar fisik dan latar sosial dalam sebuah novel. Selain itu, diharapkan dapat memaparkan interpretasi mengenai latar tersebut.

Novel Pertemuan Dua Hati yang selanjutnya disingkat PDH karya Nh. Dini adalah sebuah novel Indonesia modern yang mengisahkan tentang perjuangan seorang wanita. Seorang istri yang juga seorang ibu dari keluarga sederhana, bahkan sering kekurangan dalam memenuhi kebutuhan sehari-hari. Namun, ia tetap menciptakan keluarga yang harmonis dan bahagia. Dia juga seorang guru yang ikut membantu suaminya mengatasi kesulitan ekonomi keluarganya. Selain itu juga tentang perjuangannya merawat anak yang menderita epilepsi kronis. Pada saat pertama mengajar, langsung berhadapan dengan salah seorang muridnya yang mengalami kesulitan, murid tersebut bernama Waskito.

Dalam novel ini dikisahkan tentang perjuangan dan keuletan $\mathrm{Bu}$ Suci dalam membimbing dan mengembalikan Waskito menjadi anak yang wajar dan normal sampai akhirnya ia naik kelas.

Novel Pertemuan Dua Hati menyajikan kisah kehidupan seorang guru dan ibu dalam mendidik putra-putranya. Dengan membaca novel Pertemuan Dua Hati, guru dan orang tua akan semakin memahami tentang pendidikan anak-anaknya. Novel ini cukup selaras dibaca oleh kalangan pendidik, orang tua dan seluruh masyarakat.

Penulis merasa tertarik untuk meneliti karya Nh. Dini dengan pertimbangan bahwa: a) sebagai penulis, Nh. Dini sudah dikenal masyarakat sejak tahun 1950-an lewat karya pertamanya yang berjudul Dua Dunia (kumpulan cerpen, 1956). b) Nh. Dini telah menulis banyak buku sastra, berupa kumpulan cerpen, novel dan memoar. c) Penulis Nh. Dini merupakan penulis watak yang baik. Gerak-gerik kecil pelakunya dia tangkap dalam upaya memberikan gambaran watak yang lebih tepat. Pelukisan perasaan manusi dapat dilukiskan dengan baik. Nh. Dini selalu cermat dalam menggambarkan setiap tokoh, selalu lengkap dan mendalam. Pembaca diajak ikut dalam jalinan kalimat yang kreatif dan tidak klise.

Dihubungkan dengan kurikulum Bahasa dan Sastra Indonesia untuk SMP, penelitian tentang latar dalam novel sesuai dengan tuntutan KTSP yaitu membahas 
tema, dan latar yang terdapat dalam cerpen, novel, dan drama.

Berdasarkan uraian tersebut di atas, maka penulis tertarik untuk meneliti novel Pertemuan Dua Hati dengan mengkaji latar fisik dan latar sosialnya.

Berdasarkan latar belakang masalah yang telah disebutkan di atas, maka masalah dalam penelitian ini adalah bagaimanakah latar fisik dan latar sosial yang tercermin dalam novel Pertemuan Dua Hati karya Nh. Dini?

Sesuai dengan latar belakang masalah yang telah disebutkan di atas, tujuan penulisan laporan penelitian ini adalah untuk menginterpretasikan latar fisik dan latar sosial novel Pertemuan Dua Hati karya Nh. Dini.

Adapun manfaat penelitian ini adalah sebagai berikut :

1) Sebagai salah satu bahan acuan dalam mengajarkan materi apresiasi sastra. Terutama tentang latar dalam sebuah novel.

2) Sebagai bahan penunjang penelitian yang lain. Penelitian ini dapat membantu peneliti lain terutama yang mengkaji sastra novel dan tentang Nh. Dini.

\section{LANDASAN TEORI \\ Pengertian Novel}

Novel berasal dari bahasa Itali, juga dari bahasa Latin yakni novellus yang diturunkan pula dari kata novies yang berarti baru. Dikatakan baru karena kalau dibandingkan dengan jenis-jenis sastra lainnya seperti puisi, drama, dan lain-lain, maka jenis novel ini muncul kemudian (Tarigan, 1984:164).

Sastra dalam konteks ini novel adalah suatu karangan prosa yang bersifat cerita yang menceritakan suatu kejadian yang luar biasa dari kehidupan orang-orang (tokoh cerita) (Suroto, 1990: 19).

Menurut Fuadi (2016:132) novel adalah cerita atau prosa panjang yang mengandung rangkaian cerita kehidupan seseorang dan orang-orang di sekelilingnya dengan menonjolkan watak dan sifat setiap pelaku.

Selanjutnya Sumarjo dalam Sentosa dan Wahyuningtyas (2010:47) mengatakan bahwa novel diartikan sebagai novel adalah produk masyarakat. Novel berada di masyarakat karena novel dibentuk oleh anggota masyarakat berdasarkan desakandesakan emosional atau rasional dalam masyarakat.

Berdasarkan pengertian tersebut di atas dapat disimpulkan bahwa novel adalah salah satu bentuk karya sastra yang merupakan ungkapan pribadi pengarangnya berdasarkan pengalaman, pemikiran, perasaan, ide, semangat, serta keyakinan dalam suatu bentuk gambaran kongkret yang membangkitkan pesona dengan alat bahasa.

\section{Pengertian Latar (Setting)}

$$
\text { Menurut Sudjiman }
$$

mengartikan latar atau setting sebagai segala keterangan, petunjuk, pengacuan yang berkaitan dengan waktu, ruang dan suasana terjadinya peristiwa dalam suatu karya sastra. Pendapat ini sejalan dengan pendapat Abrams dalam Priyadi (1994:64) yang mengartikan latar sebagai tempat secara umum, waktu dan lingkungan sosial tempat terjadinya peristiwa. Siswandarti (2009:44) juga menegaskan bahwa latar adalah pelukisan tempat, waktu, dan situasi atau suasana terjadinya suatu peristiwa.

Robert Stanton dalam Priyadi (1994:64) mengatakan bahwa latar atau tandas tumpu adalah lingkungan tempat peristiwa terjadi. Latar tempat atau ruang yang diamati (kampus, kapal, kafetaria, penjara, Hongkong, Paris, dll) dan orang atau kerumunan orang di sekitar tokoh.

Sementara itu pendapat Jakob Sumardjo dalam Aeini (1995:25) mengemukakan bahwa latar adalah tempat bermain sebuah cerita. Latar bukan hanya terbatas pada pengertian geografis, tetapi juga antropologis. Lebih lanjut Sumardjo dan Saini (1991:76) mengatakan latar atau setting cerita bukan hanya menunjukkan 
tempat dan waktu tertentu tetapi juga hal-hal yang hakiki dari suatu wilayah, sampai pada debu pemikiran rakyatnya, kegilaan mereka, gaya hidup mereka, kecurigaan mereka dan sebagainya. Sehingga latar atau setting cerita bukan hanya menunjukkan tempat, waktu dan sarana dalam cerita seperti yang kita kira-kira sebelumnya, tetapi mencakup berbagai pola tingkah laku kehidupan masyarakat tertentu.

\section{Macam-macam latar}

Dari Pengertian latar sebagaimana disebutkan di atas, Hudson dalam Sudjiman (1991:44) membagi latar menjadi dua yaitu (1) latar material atau fisik dan (2) latar sosial. Latar material atau fisik dikukuhkan oleh hal-hal yang kongkret. Hal-hal yang kongkret merupakan hal yang visual, badaniah, teraba. Misalnya tempat tinggal, peralatan rumah tangga, bentuk kesenian, daerah dan lain-lain. Sedangkan latar sosial lebih bersifat abstrak. Misalnya konsep nilai dalam masyarakat, adat istiadat, kepercayaan, sistem politik, ekonomi, sikap hidup, pandangan hidup dan lain-lain (Priyadi, 1994:97).

Menurut Abrams dalam Aeini (1995:27) latar dapat dikategorikan menjadi latar sosial, latar tempat atau geografis, dan latar waktu atau historis.

Dari pendapat Marjorie Boulton, Lostracco, dan Wilkerson dalam Priyadi (1994:67) dapat disimpulkan bahwa latar ada dua yakni latar dalam pengertian yang sempit dan latar dalam pengertian yang luas. Dalam pengertian yang sempit, yang dimaksud dengan latar adalah tempat dan waktu terjadinya peristiwa. Sedangkan dalam pengertian yang luas, latar menunjuk pada keseluruhan lingkungan fisik, ekonomi, sosial (sistem kekerabatan, sistem religi dan lain-lain), politik, dan psikologi.

\section{METODE PENELITIAN}

Metode yang digunakan dalam penelitian ini adalah metode deskriptif. Metode ini digunakan untuk mendeskripsikan latar fisik dan latar sosial novel Pertemuan Dua Hati karya Nh. Dini.

Adapun model penelitian yang digunakan adalah penelitian kualitatif Bogdan dan Biklen dalam Semi (1993:24) menuliskan bahwa penelitian kualitatif bersifat deskriptif. Hal ini mengandung arti bahwa dalam melakukan kajian tidak menggunakan perhitungan angka-angka tetapi dipaparkan dengan menggunakan kata-kata berdasarkan data penelitian.

Selanjutnya sumber data berasal dari Novel Pertemuan Dua Hati karya Nh. Dini yang berjumlah 85 halaman, diterbitkan oleh PT Gramedia Pustaka Utama Jakarta merupakan cetakan keenam pada bulan Oktober 1992.

Pendekatan dalam penelitian ini adalah pendekatan struktural atau pendekatan analitik. Pendekatan ini bertolak dari asumsi dasar bahwa karya sastra sebagai karya kreatif memiliki otonomi penuh yang harus dilihat sebagai suatu sosok yang berdiri sendiri terlepas dari hal-hal lain yang berada di luar darinya (Semi, 1993:67).

Teknik dan alat pengumpul data yang digunakan dalam penelitian ini adalah teknik studi dokumenter. Yaitu dengan membaca secara berulang dan membuat catatan sesuai dengan permasalahan yang dirumuskan. Dengan kata lain dalam memecahkan masalah penelitian, peneliti merujuk pada literatur-literatur yang relevan dengan permasalahan penelitian.

Adapun langkah-langkah yang ditempuh dalam menganalisis data sebagai berikut :

1) Membaca novel Pertemuan Dua Hati karya Nh. Dini secara berulang-ulang untuk melakukan verifikasi.

2) Mendeskripsikan data. Data yang ada dipaparkan atau digambarkan apa adanya dengan menggunakan kata-kata secara jelas.

3) Interpretasi data. Data yang sudah dideskripsikan kemudian ditafsirkan berdasarkan masalah penelitian. Data penelitian diinterpretasikan untuk 
mengungkapkan latar fisik dan latar sosial novel Pertemuan Dua Hati karya Nh. Dini.

\section{PEMBAHASAN}

\section{Deskripsi Latar Fisik Novel Pertemuan Dua Hati}

Novel Pertemuan Dua Hati dimulai dari rumah yang dikontrak berukuran besar, kamarnya hanya ada dua, bentuk ruang tengah memanjang dengan kamar mandi, sumur dan kamar kecil ada di dalamnya.

Selanjutnya digunakan nama kota Purwodadi sebagai tempat aku yang bernama Bu Suci menjadi guru waktu itu. Hamper sepuluh tahun aku mengajar di kota kelahiranku. Sehingga beberapa bulan yang lalu suamiku dipindahkan perusahaannya ke kota besar ini.

Seperti kota-kota pesisir lain, Semarang sudah ku kenal ketika aku bersekolah disana. Kepadatan penduduk dikuasai pengaruh golongan Tionghoa. Sekolahku terletak di bagian kota atas yang dinamakan daerah candi. Untuk pergi ke kota bawah harus naik "daihatsu" sebutan kendaraan karena lazimnya mobil bermerek daihatsu.

Suamiku mendahului pindah ke Semarang. Hal tersebut karena kantor di kota memerlukan dia sebagai ahli mesin. Semarang sebagai kota pelabuhan merupakan pintu gerbang berbagai pengaruh. Kebiasaan dan tradisi yang dipertahankan oleh sekelompok masyarakat, dibagian bagian tertentu kota ini bercampur dengan kebiasaan baru. Rumah-rumah terlalu berdekatan. Rumah tetangga menyuarakan kaset-kaset secara bersamaan dengan lagu yang berbeda.

Rumah RT itu mentereng. Berhalaman luas. Tetapi itu bukan satu-satunya rumah bagus di dalam kampung kami yang baru. Sepintas lalu aku sudah melihat tempat kediaman lain yang mewah dan modern.

Sewaktu tinggal di Purwodadi, kami menempati setengah batu setengah kayu. Letaknya di pinggir jalan. Sepuluh tahun yang lalu jalan itu belum ramai. Ketika kami meninggalkannya, lalu lintas sudah sangat padat.

Daerah kami disebut orang daerah minus. Desa-desa mempunyai sawah, tetapi tidak pernah menghasilkan berlimpahlimpah. Rakyat berduyun-duyun meninggalkan kehidupan bercocok tanam. Semarang adalah kota yang digemari sebagai sasaran mencari nafkah.

Pindah ke Semarang, kami tinggal di daerah pinggiran kota. Dimasa sekolah, daerah itu masih merupakan pinggiran yang kosong, meskipun mulai berkembang perlahan menjadi perkampungan liar. Namanya Mrican. Terletak di kota sebelah tenggara.

Pada hari-hari tertentu, pasar ini juga menjadi pasar hewan. Bermacam-macam binatang ternak diperjualbelikan.

Setelah dua bulan di rumah baru, kami mapan. Ruang tengah yang panjang kujadikan ruang keluarga. Di pojok kuletakkan televisi. Di dekat dinding yang bertentangan ada seperangkat meja kursi untuk makan. Itu juga kami pergunakan sebagai tempat menggarap pekerjaan rumah, menulis atau menjahit. Di depan televisi kugelar tikar pandan anyaman dua permukaan yang di daerah kami disebut tikar pasir. Tebal dan lunak, member rasa santai bagi yang duduk di atasnya. Pasangan meja kursi rotan diletakkan di dekat pintu masuk. Vernisnya harus diperbaharui. Suamiku juga harus membuat rak buku. Hal tersebut akan dikerjakan setelah mengambil cuti waktu lebaran kelak.

Hari itu kami naik becak ke sekolah. Bersama anak sulungku, kami berlomba mencari pohon mangga yang tumbuh di sepanjang jalan. Halaman rumah kota besar jarang ditanami buah-buahan. Barangkali karena kami tinggal jauh dari pusat, kami masih menemukan lebih dari lima pohon. Kemudian kami menerka jenis pohon mangga apa. Warna bunganya pun berlainan. Ada yang kuning jernih. Ada yang agak kemerah-merahan atau coklat muda. Anakku 
membandingkan tempat tinggal kami yang sekarang dengan Purwodadi.

Setelah melewati pasar, jalan menuju ke sekolah menurun. Di situ kelihatan bagian kota yang paling baru. Kebanyakan gedung bergaya sesudah perang. Sehingga banyak sekolah menonjol kekunoannya. Nampak anggun meskipun warnanya sudah lusuh, terlalu lama tidak dicat. Sebelum becak berhenti di depannya, aku berkata kepada anak sulungku : "lihat di Purwodadi tidak ada sekolah sebagus ini". "Apanya yang bagus?" suara anakku kedengaran lugu. "Perhatikan baik-baik. Atapnya lain dari atap di sana itu. Gedungnya demikian pula. Bentuk tiang dan pintunya. Tidakkah kamu menyukainya? Di zaman sekarang tidak banyak gedung seperti ini."

Untuk mengatasi masalah murid yang bernama Waskito, aku mengirim surat kepada nenek Waskito. Pada suatu sore yang telah ditentukan, aku berkunjung ke rumah kakek dan nenek tersebut. Kini setelah duduk, baru beberapa menit berkenalan dan melihat keterbukaan hari wanita itu, aku merasa kerasan. Kami berada di rumah bagian belakang. Teras itu kelihatan ditambahkan setelah rumah selesai dibangun. Sekelilingnya dibatasi oleh dinding setinggi lutut, penuh pot tanaman. Seluruh kebun tidak begitu luas. Dari kursiku, aku dapat memandang sebagian daripadanya. Jauh di sudut, Nampak pohon pisang menggerombol menabiri tempat jemuran. Di dekatnya, anyaman bambu menyangga jaluran tanaman pare. Buahnya begantungan hijau muda menyedapkan mata. Di pinggir ada pohon papaya, dua berjejeran. Agak ketengah, pohon jambu air. Buahnya masih muda membentuk kelompokkelompok bagaikan lampu tertempel rapi di dahan dan ranting. Sebentar lagi mereka akan menjadi merah kesumba menggiurkan. Semuanya sederhana di sana. Tetapi kesan kekeluargaan juga besar.

Letak kampung kami bersambungan dan berdampingan dengan kampungkampung lain. Untuk menuju ke jalan besar, kami harus melewati satu atau dua kelompok pemukiman tersebut. Menurut berita, Waskito mempunyai sebuah kamar yang kelihatannya rapi terpelihara. Alat-alat pertukangan terkumpul di suatu lemari kecil lengkap dengan mejanya. Selesai digunakan, Waskito segera mengembalikan ke tempat semula.

Di dalam kamar itu juga bergantungan model-model pesawat. Pesawat-pesawat itu dibuatnya menuruti gambar di buku.

\section{Deskripsi latar sosial Novel Pertemuan Dua Hati.}

Ketika aku lulus SD, orang tuaku menasehatkan agar masuk ke sekolah guru. Untuk membujukku ibuku menambahkan bahwa libur guru sama panjangnya dengan anak sekolah. Melebihi orang yang bekerja di kantor.

$\mathrm{Aku}$ bercita-cita menjadi seorang sekretaris. Aku sering melihat gadis atau wanita muda yang mengetik dan mengurus kantor. Mereka selalu berpakaian bagus. Tata rambut maupun dandanan baju senantiasa rapi. Mereka kelihatan lebih cantik dan menarik daripada guru yang mengajarku. Waktu itu umurku masih sangat muda. Yang kuketahui, pekerjaan sekretaris hanyalah sebagai juru tulis. Keberesan kantor kukira sama dengan keberesan rumah tangga yang kusaksikan sehari-hari. Setelah dewasa, barulah aku mengetahui betapa rumit dan sukar menjadi sekretaris.

Aku anak yang patuh. Aku diantarkan bapak mendaftarkan diri di SPG Semarang. Kebahagiaan yang kurasa karena baru pertama keluar dari rumah. Tambah lagi, saat pulang berlibur bertemu orang tua dan tempat kelahiran.

Lulus SPG aku ingin melanjutkan ke IKIP. Meskipun kemampuan otak memadai bapak tidak sanggup membiayai. Adikku ada tiga orang, sehingga mencari nafkah ketimbang mengikuti program ikatan dinas lebih diharapkan.

Aku dididik orang tua agar hidup sebisa mungkin. Segala perselisihan 
pendapat diselesaikan dengan terbuka dan terus terang. Tetapi dalam kenyataan hidup sehari-hari aku lebih sering mengalah.

Agar biaya hidup tidak terlalu menekan bahu suamiku, aku harus kembali mengajar secepat mungkin. Menurut pendapatku, justru pada tingkat sekolah dasar sebaiknya anak- anak menerima pendidikan sepatutnya.

Sebagai orang baru dan untuk memenuhi tata cara aku memperkenlkan diri ke Rukun Tetangga. Aku bertemu dengan isteri RT, sebab suaminya sedang mengurus keperluan lain. Ramah dan sopan dia menyambutku. Dia menjadi anggota perkumpulan cukup banyak sehingga mengenal banyak orang.

Setelah menyelesaikan masalah lingkungan, aku berhadapan dengan tugasku. Kepala sekolah usul agar aku masuk dan mengajar dua kelas. Bagaimanapun besarnya cintaku kepada pekerjaan sebagai guru. Tanpa menunggu habisnya bulan itu, aku mulai mengajar.

Belum lama mengajar, anakku yang kecil sakit. Pendapat tetangga kemudian ditanggapi oleh uwakku bahwa anakku tidak cocok dengan "penjaga" rumah kami. Dan cara berpikir uwak hampir berhasil menjalari suamiku dan aku ketika beberapa hari mulai mengajar anakku tiba-tiba diserang panas atau demam keras. Suamiku tidak di rumah. Dengan menyewa Daihatsu anakku dibawa ke dokter. Setelah diperiksa dokter, namun tidak dijelaskan mengapa anakku sampai kejang-kejang.

Anakku yang kedua terus minum obat dan tidak mau tinggal di rumah. Akhirnya dia masuk sekolah dengan diantar. Kami bertiga naik becak dengan sulungku. Diperjalanan terjadi perbincangan antara aku dan anakku. "Di Purwodadi, Bapak tidak pernah pulang terlambat," tanpa kuduga, anak sulungku menambahkan.

Aku agak terkejut. Mungkin telah lama ditahannya. $\mathrm{Ku}$ coba menjelaskan letak kantor bapaknya yang jauh dari Purwodadi.
Selain masalah anak aku juga menghadapi masalah murid karena tugasku sebagai pendidik. Hari keempat masuk sekolah, aku mencari tahu tentang Waskito. Seisi kelas seperti bisu. Akhirnya diketahui dari penjelasan teman-teman Waskito bahwa dia sering memukul teman sekelas. Temannya berkata dulu Waskito tinggal bersama neneknya. Kemudian diambil oleh orang tuanya. Dari keterangan murid-murid kesimpulan yang dapat diambil sementara bahwa Waskito tidak berpura-pura dan ada kesulitan yang menggugah perasaanku untuk mengetahui lebih lanjut.

Persoalan murid tidak kubawa ke rumah. Rumah tempat keluarga dan bukan untuk mengeruhkan suasana dengan masalah dari luar rumah.

Aku mengirim surat kepada neneknya dan ditanggapi. Pada hari yang ditentukan aku mengunjungi nenek Waskito. Dari keterangan neneknya bahwa setelah orang tuanya tahu tentang keadaan Waskito belakangan sehingga dihajar habis-habisan.

Setengah tahun dititipkan dengan neneknya, rapor Waskito menunjukkan kemajuan. Namun sepertinya Waskito tidak pernah mendapat kesempatan untuk berpendapat seperti menentukan pilihan dia harus bersama siapa. Dapatkah aku menolongnya keluar dari persoalannya?

Sampai di rumah aku melupakan persoalan murid termasuk Waskito. Kami prihatin melihat anak kedua yang mengidap elektroensefalografik yang biasa disebut EEG. Berdasarkan kepercayaan kepada para ahli, kami berhasil menemukan kembali sedikit rasa ketenteraman. Yang disebut pasrah dalam filsafat Jawa juga sangat membantu. Dua hari terakhir, aku berturutturut ke dokter perusahaan dan rumah sakit. Untuk sementara selesailah pemeriksaan anakku. Tinggal berobat jalan atau mengambil obat jika habis.

Kemudian aku kembali mengajar. Beberapa saat aku berada di kantor. Tibatiba kulihat Waskito masuk, menuju ke tempatku. Tanpa berkata sesuatupun, dia 
meletakkan timbunan buku tugas di depanku.

$\mathrm{Aku}$ terpesona. Heran bercampur bingung, masih bisa mengucapkan: "terima kasih. Nanti akan saya periksa." Hari-hari selanjutnya menyusul kejadian-kejadian lain. Waskito masih sering mengganggu temannya. Namun dalam banyak hal Waskito mengubah sikap menjadi lebih patuh. Aku terus menerus mengamati perkembangan kelas. Sebulan berlangsung aku dapat tabah mengalami loncatanloncatan kebiasaan Waskito.

Hatiku mulai agak tenang. Meskipun ketenangan itu kesiagaan untuk menghadapi kejutan. Baik itu dari pihak murid sukarku maupun anakku.

Karena bukan hanya Waskito yang tertarik tentang pabrik rakyat maka aku merencanakan menunjukkan teori bejana berhubungan di kelasku. Murid-murid diberi tugas. Hari pengumpulan tiba, masingmasing regu membawa hasil kerja mereka. Ternyata pekerjaan regu Waskito yang paling baik dan rapi. Keterangan regunya mengatakan bahwa yang mampu mengerjakan hanya Waskito karena memiliki peralatan sendiri. Kejadian ini membesarkan hatiku.

Hampir tiga bulan aku bekerja, keadaan dapat dikatakan dapat dikatakan tenang. Tiba-tiba keadaan berubah. Seorang muridku terengah-engah datang, langsung berseru : "Bu Suci. Waskito kambuh, Bu. Dia mengamuk. Dia mau membakar kelas". Semua bergerak menuju kelas. Waskito memegang gunting. Aku merampas guntingnya dan diberikan kepada kepala sekolah.

Semua terjadi begitu cepat bagaikan kejapan mata. Dengan susah payah aku mempertahankan muridku. Guru-guru lain ingin mengeluarkannya. Aku memohon kepada kepala sekolah untuk diberi waktu. Walaupun usul tersebut ditanggapi dengan jengkel seorang guru. Aku meminta waktu satu bulan.
Aku kembali ke kelas setelah rapat. Kemudian aku mengganti tempat duduk murid kelasku. Kuberi pengertian tentang kedudukanku dan masalah anakku. Hingga waktu pulang, Waskito tetap duduk di tempatnya semula.

Malamnya aku gelisah. Tidurku sangat mengganggu. Keesokan harinya, ketika lonceng berbunyi aku masuk kelas. Waskito telah berpindah tempat, duduk tepat di depan meja guru. Hari itu berlalu dengan tenang. Aku bersyukur menyebut nama tuhan.

Waskito masih suka merusak tanaman temannya. Sehingga Waskito perlu diberi pengertian bahwa merusak tanaman juga telah membunuh. Waskito tidak masuk kelas. Akhirnya kutemukan Waskito di selokan. Dia mengatakan bahwa temannya mengejeknya. Akhirnya mau kembali ke kelas. Kejadian itu merupakan tambahan yang melengkapi pertemuan hari Waskito dan hatiku.

Akhir tahun pelajaran. Waskito naik kelas. Bu Denya datang ke sekolah. Dia berterima kasih kepada kepala sekolah, para guru, dan kepadaku. Aku menjawab bahwa aku gembira dapat menolong Waskito.

\section{Interpretasi latar fisik Novel Pertemuan Dua Hati}

Keterangan mengenai rumah

Keterangan mengenai rumah dalam novel PDH Karya Nh. Dini dimulai dengan, "rumah yang dikontrak suamiku besar". Selanjutnya dijelaskan bahwa kamarnya hanya dua, ruang tengah memanjang, ada kamar mandi, sumur dan kamar kecil di dalamnya.

Rumah tersebut cukup ideal untuk jumlah keluarga lima orang. Gambaran kongkret mengenai rumah dan isinya yakni setelah dua bulan tinggal di rumah baru.

Kami mulai mapan. Barang-barang sudah menemukan tempatnya masing-masing. Ruang tengah yang memanjang kujadikan ruang keluarga. Di pojok kuletakkan televisi. Di dekat dinding yang bertentangan, ada seperangkat meja-kursi 
untuk makan. Itu juga kami pergunakan sebagai tempat menggarap pekerjaan rumah, menulis atau menjahit. Di depan televisi kugelar tikar pandan anyaman dua permukaan yang di daerah kami disebut tikar pasir. Tebal dan lunak, member rasa santai bagi yang duduk di atasnya. Pasangan meja-kursi rotan diletakkan di dekat pintu masuk (Dini, 1992:17-18)

Ternyata kehidupan tokoh mulai mapan. Semua perlengkapan rumah cukup bahkan ada televisi. Walaupun tidak dijelaskan TV warna atau hitam putih.

Rumah RT juga mentereng dan berhalaman luas. Ternyata cukup banyak rumah bagus. Sehingga melihat rumah RT dan sekitarnya menimbulkan kesan mewah dan modern. Jika dibandingkan tempat tinggal mereka dulu di Purwodadi yang setengah batu dan setengah kayu tentu jauh berbeda. Keterangan rumah tersebut memberikan kesimpulan bahwa disekitar tempat tinggal sang tokoh kehidupan tetangga-tetangganya cukup mewah dan modern.

Teras bagian belakang rumah kakek dan nenek Waskito dibatasi oleh dinding setinggi lutut, penuh pot tanaman. Ada kebun pisang, kebun pare, pohon-pohon pepaya, dan pohon jambu air. Semuanya menimbulkan kesan sederhana. Kakek Waskito yang masih praktik di rumah sakit masih sempat berkebun. Walaupun tidak dijelaskan dikerjakan oleh tukang kebun atau memang kakek Waskito.

Sebetulnya Waskito adalah anak yang cukup terampil walaupun sebetulnya digambarkan sebagai anak yang sukar di sekolah. Kamarnya rapi dan terpelihara. Bagian ini juga belum dijelaskan tentang orang yang merapikan kamar Waskito atau memang Waskito rajin merapikan kamarnya. Keterangan yang memaparkan bahwa Waskito mampu membuat model-model pesawat yang dicontohnya dari gambar. Alat-alat pertukangannya terkumpul dalam lemari kecil lengkap denan mejanya. Jika dia menggunakan alat-alat pertukangannya setelah selesai tidak dibiarkan berantakan, tetapi segera dikembalikan ke dalam kotaknya.

Waskito selain terampil juga sayang terhadap alat-alat pertukangannya. Penggambaran atau keterangan mengenai rumah cukup memadai sehingga dapat ditelaah tentang kondisi rumah dalam cerita novel Pertemuan Dua Hati.

\section{Keterangan mengenai daerah}

Keterangan mengenai daerah dalam novel PDH sebagai berikut:

Purwodadi adalah tempat kelahiran $\mathrm{Bu}$ Suci sang tokoh. Purwodadi kota kecil, gersang, tanpa daya tarik (Dini, 1992:9).

Kota kecil tersebut tetap dikenang sang tokoh sebagai kota kelahirannya. Penilaiannya bahwa kota tersebut gersang dan tanpa daya tarik.

Daerah yang sering disebut tempat kehidupan sang tokoh adalah Semarang. Kota pelabuhan yang merupakan pintu gerbang berbagai pengaruh. Rumah-rumah berdekatan. Bagian-bagian tertentu kota ini bercampur dengan kebiasaan baru.

Kepadatan penduduk dikuasai pengaruh golongan Tionghoa (Dini, 1992:10).

Kota ini terbagi dua, yakni kota atas yang dinamakan kota Candi, dan kota Bawah yang ditempuh dengan naik "Daihatsu". Orang disana tidak berkata naik mobil atau naik oplet. Hal tersebut disebabkan merek mobil angkutan umum adalah Daihatsu.

Bagian kota yang paling baru yakni setelah melewati pasar menuju sekolah. Banyak gedung bergaya sesudah perang. Hal yang menonjol adalah kekunoannya. Meskipun catnya sudah lusuh namun terlihat anggun.

Keterangan tersebut di atas rasanya cukup untuk dikhayalkan oleh pembaca. Begitu juga tentang atap sekolah yang lain. Atap tersebut tidak dijelaskan lainnya seperti genteng atau seng. Namun pembaca 
mencoba menangkap sebagai bangunan atap yang kuno.

Letak kampung kami bersambungan dan berdampingan dengan kampungkampung lain. Untuk menuju ke jalan besar, kami harus melewati satu atau dua kelompok pemukiman tersebut (Dini, 1992:62).

Keterangan mengenai kampung mudah dipahami karena setiap desa biasanya berdekatan. Begitu juga mengenai pemukiman penduduk, lebih sering berkelompok-kelompok.

Keterangan mengenai daerah juga bagus. Purwodadi kota kelahiran. Semarang tempat tinggal mereka juga tempat mencari nafkah. Juga tentang kota Semarang yang terbagi dua yaitu kota atas dan kota bawah dan kebiasaan penduduk.

\section{Interprestasi latar sosial Novel Pertemuan Dua Hati}

\section{Keadaan Ekonomi Masyarakat}

Kondisi ekonomi masyarakat di sekitar tempat tinggal tokoh yang baru sangat layak. Hal tersebut dapat dilihat dari gambaran rumah yang mentereng. Rumah RT ternyata bukan satu-satunya rumah mewah. Artinya hamper semua rumah kondisinya mewah dan penghuninya memiliki taraf ekonomi yang lebih dari cukup. Rumah sang tokoh walau cuma dua kamar, tetap terlihat agak besar. Untuk menanggulangi perekonomian keluarga sang tokoh yang kedudukannya sebagai isteri juga turut mencari nafkah. Sehingga dalam dua bulan tinggal di Semarang, kehidupannya mulai mapan.

Kami mulai mapan(Dini, 1992: 17). Aku memilih menjadi pendidik, bagi anakanakku dan murid yang dipasrahkan kepadaku. Gaji atau penghargaan seringkali meleset, tidak sesuai dengan jasa yang secara rendah hati kami sumbangkan bagi pembangunan watak tiang masa depan bangsa. (Dini, 1992:85)
Walaupun gaji guru sering terlambat tetapi sang tokoh adalah orang yang percaya pada tuhan. Sehingga walau hanya sebagai guru, sang tokoh telah ikut menopang perekonomian keluarga sampai mapan. Keadaan ekonomi digambarkan sangat makmur. Jadi ekonomi tokoh cerita dari sangat sederhana menjadi mapan.

\section{Pandangan hidup}

Aku bercita-cita menjadi sekretaris. (Dini, 1992:9).

Sewaktu sang tokoh berumur masih sangat muda, memiliki cita-cita menjadi seorang sekretaris. Mereka terlihat sangat cantik dari guru yang mengajarnya. Rambut dan dandanan baju sangat rapi.

Setelah dewasa, barulah aku mengetahui betapa rumitnya dan sukar menjadi sekretaris yang baik (Dini, 1992:9).

Pekerjaan guru bukan pilihan sang tokoh, tetapi pilihan orang tua.

$\mathrm{Aku}$ patuh, menuruti nasihat orang tua (Dini, 1992:10).

Sang tokoh anak yang patuh sehingga ketika orang tua mengantar ke Semarang masuk SPG, sang tokoh ternyata tidak menyesal. Ibunya berkata bahwa guru merupakan pekerjaan yang cocok untuk wanita. Libur guru sama panjangnya dengan anak sekolah, ibunya menambahkan.

Sang tokoh tidak mencampuradukkan masalah rumah dengan sekolah.

Persoalan murid sukar tidak pernah kubawa ke rumah (Dini, 1992:34).

Ternyata sang tokoh masih mampu memisahkan masalah pekerjaan dengan masalah rumah. Masalah rumah ialah anak kedua sakit parah. Persoalan pekerjaan adalah tentang Waskito, murid sukar. Ketika kedua masalah tersebut memuncak, pandangan tersebut menjadi kabur. 
Aku tidak dapat lagi mempertahankan kebiasaan lamaku memisahkan keluraga dari sekolah (Dini, 1992:74).

Sebagai manusia biasa pandangan mengenai kehidupan luar jangan digabungkan dengan kehidupan rumah tangga tidak selamanya dipertahankan.

Ada pernyataan akhir bahwa pekerjaan sebagai guru sebenarnya sesuai dengan hati nurani sang tokoh.

Aku memilih menjadi pendidik, bagi anak-anakku dan murid yang dipasrahkan kepadaku (Dini, 1992:85).

Kalimat tersebut mengisyaratkan bahwa menjadi guru atau pendidik merupakan suatu pengabdian tulus bagi anak-anak bangsa. Artinya sang tokoh memiliki pandangan bahwa sebagai guru merupakan pekerjaan yang mulia.

Pandangan hidup sang tokoh cukup jelas yakni bercita-cita menjadi sekretaris. Menjadi guru pada akhirnya ditekuni karena memang pantas untuk wanita. Begitu juga pandangan sang tokoh yang tidak ingin mencampuradukkan masalah pribadi atau di rumah dengan pekerjaan di sekolah.

\section{Sikap hidup}

Sang tokoh adalah wanita yang patuh terhadap orang tua. Juga seorang yang menjalankan ibadah sesuai dengan keyakinannya. Bu Suci adalah seorang guru yang sangat perhatian terhadap muridmuridnya. Juga sebagai ibu yang bertanggungjawab terhadap keluarganya.

Menghadapi kenyataan bahwa muridnya mengalami kesulitan, ia berusaha sebisa mungkin untuk mendidik dan meluruskan murid-muridnya. Dia tampil membawa anak-anaknya ke dokter ketika suaminya tidak di rumah. Dia juga ikut bekerja agar kehidupan mereka menjadi mapan.

Dia adalah wanita yang sabar menghadapi masalah. Ketika murid sukarnya membuat masalah lagi, dia masih memohon meminta waktu memperbaiki murid sukarnya. Dia tidak peduli dengan cemoohan rekan gurunya. Kembali ke rumah dia berupaya mengobati anaknya yang sakit keras.

Sang tokoh merupakan tokoh yang selalu ingin tahu. Dalam arti sangat bertanggungjawab mencari keterangan mengenai murid sukarnya. Guru-guru tidak peduli dengan masalah Waskito, dia tidak peduli.

$\mathrm{Bu}$ Suci adalah tokoh yang terpesona. Melihat murid sukarnya mengalami perubahan yakni mau membawa dan meletakkan buku-buku di atas meja, dia terpesona. Jauh di dalam hatinya berharap bahwa murid sukarnya mengalami perubahan yang lebih berarti atau menjadi normal. gelisah.

Sang tokoh juga seorang tokoh

Tidurku sangat terganggu (Dini, 1992:71).

Dia sangat memperhatikan dan merasa paling bertanggungjawab terhadap sikap murid sukarnya.

Dia juga seorang tokoh yang tenang. Sikap hidupnya sangat wajar, berusaha selalu tenang. Meskipun tetap dalam kesiagaan untuk berhadapan dengan sesuatu kejutan.

Dalam menghadapi Waskito, sang tokoh menganggapnya sebagai anak remaja.

Berhadapan dengan dia aku memutuskan mengambil sikap seolah-olah berhadapan dengan remaja betul-betul (Dini, 1992:56.)

$\mathrm{Bu}$ Suci adalah sosok guru ideal. Seorang wanita yang bertanggung jawab. Selain itu juga seorang yang bijaksana dalam menghadapi setiap persoalan yang dihadapi.

Sikap hidup sang tokoh yakni menjalankan ibadah, bertanggung-jawab terhadap masalah di rumah dan pekerjaan, mudah terpesona. Walaupun gelisah juga 
berupaya untuk tetap tenang. Singkatnya sikap hidup sang tokoh telah digambarkan dengan cermat.

\section{PENUTUP}

\section{Simpulan}

Berdasarkan hasil analisis atau kajian terhadap latar fisik dan latar sosial Novel Pertemuan Dua Hati Karya Nh. Dini dapat disimpulkan bahwa latar fisik yang disajikan meliputi keterangan mengenai rumah dan tempat tinggal sang tokoh telah dipaparkan dengan kongkret. Selanjutnya keterangan mengenai daerah juga disajikan dengan jelas dan nyata. Sedangkan latar sosial yang digambarkan meliputi keadaan ekonomi masyarakat sekitar tokoh sangat layak dan mewah, sedangkan perekonomian sang tokoh pas-pasan sehingga sebagai seorang istri turut mencari nafkah sebagai seorang guru. Pandangan hidup atau cita-cita tokoh yang ingin menjadi sekretaris akhirnya pupus karena pilihan orang tuanya untuk menjadikan dirinya sebagai seorang guru. Sikap sang tokoh yakni patuh terhadap orang tua, taat beribadah menjalankan perintahNya, bertanggung jawab terhadap masalah anak di rumah dan anak didik di sekolah.

\section{Saran}

Mengingat masalah penelitian hanya terbatas tentang latar, sebaiknya untuk penelitian berikutnya ada peneliti yang melanjutkan penelitian ini dari aspek yang lain. Penelitian ini dapat menunjang penelitian sastra lain terutama novel.

\section{DAFTAR PUSTAKA}

Aeini, Sri Nur. 1995. Aspek Penokohan Novel Para Priyayi karya Umar Kayam. Pontianak: FKIP Untan.

Dini, Nh. 1992. Pertemuan Dua Hati.Jakarta : PT Gramedia Pustaka Utama.

Effendy, Chairil. 1985. Novel dan Puisi Karya Kontowijoyo sebuah pembicaraan. Pontianak : FKIP Untan.

Fuadi, Deti Syamrotul Fuadi. 2016. Intisari dan Bank Soal Penunjang Pelajaran Bahasa Indonesia.Bandung : Yrama Widya.

Priyadi, Anton Totok. 1994. Tinjauan Sosiologis Sastra terhadap kumpulan cerpen senyum karyamin karya Ahmad Tohari.Malang : IKIP Malang.

Semi, M. Atar. 1993. Metode Penelitian Sastra. Jakarta: Gramedia Pustaka Utama.

Sentosa, Wijaya Heru dan Wahyuningtyas, Sri. 2010. Pengantar Apresiasi Prosa. Surakarta : Yuma Pustaka.

Siswandarti. 2009. Panduan Belajar Bahasa Indonesia untuk SMA Kelas XI. Yogyakarta : Dinas Pendidikan Menengah dan Non Formal Kabupaten Bantul.

Sudjiman, Panuti. 1991. Memahami cerita rekaan. Jakarta : Pustaka Jakarta.

Sumardjo dan Saini, K.M. 1986. Antologi Apresiasi Kesusastraan. Jakarta : Gramedia

Sumardjo dan Saini, K.M. 1991. Apresiasi Kesusasteraan. Jakarta : Gramedia Pustaka Utama

Suroto. 1990. Teori dan Bimbingan: Apresiasi Sastra Indonesia. Jakarta: Erlangga.

Tarigan, Henry Guntur. 1984. Prinsipprinsip dasar sastra.Bandung : Angkasa 